\title{
A Systematic Review of the Continuous Professional Development for Technology Enhanced Learning Literature
}

\section{Ryan Thomas Williams}

School of Social Sciences, Humanities and Law, Teesside University, Middlesbrough, Tees Valley, TS1 3BX, United Kingdom

*Corresponding Contact:

Email: ryan.williams@tees.ac.uk

\begin{abstract}
There is a large body of international research on raising the quality of education, with particular emphasis on CPD to support professional and pedagogical growth. From an educator's perspective, there is widespread agreement that effective CPD is an important component of educational success. Therefore, it is unsurprising that research interest in this area has grown, particularly in light of the digital agenda. In a TEL context, educators report one of the main barriers to effective use is the lack of training in this area. This review of literature will examine some of the key ideas that form successful TEL CPD delivery, more specifically with relation to transformative models of CPD. Likewise, the section attempts to understand the context in which educators are operating and make sense of the challenges that relate to continuing professional development (CPD). In order to fully explore this phenomenon, personal development (PD) frameworks are explored, with a specific focus on Aileen Kennedy's (2005) 9 typologies.
\end{abstract}

Key words:

Professional Development, Continuous Professional Development, Technology, Pedagogy

$12 / 10 / 2020$

Source of Support: None, No Conflict of Interest: Declared

This article is licensed under a Creative Commons Attribution-NonCommercial 4.0 International License.

Attribution-NonCommercial (CC BY-NC) license lets others remix, tweak, and build upon work non-commercially,

and although the new works must also acknowledge \& be non-commercial.

\section{INTRODUCTION}

The study is engraved through the lens of Trowler's socio-cultural theory (2008) and the notion that social interactions are important for learning. Furthermore, this review is underpinned in the author's doctoral thesis in progress titled 'An Exploration into the Pedagogical Benefits of Using Social Media: Can Educators Incorporate Social Media into Pedagogy Successfully?' This body of work forms a partial chapter from an overall literature review that examines the relationship between social media and pedagogy. It is hoped that this thesis will be submitted in October 2021. Please get in contact with the corresponding contact for a copy of thesis once completed. 


\section{REVIEW OF LITERATURE}

Both professional development (PD) and continuous professional development (CPD) are interchangeable terms that claim to 'meet the needs of teachers as learners in a changing society' (Dadds, 2014). There is a large body of international research on raising the quality of education, with particular emphasis on CPD to support professional and pedagogical growth (Darling-Hammond, 2006). From an educator's perspective, there is widespread agreement that effective CPD is an important component of educational success (Atencio et al., 2012; Darling-Hammond et al., 2009).

Therefore, it is unsurprising that research interest in this area has grown, particularly in light of the digital agenda. More specifically, there are those who argue for CPD to be embedded in teachers' daily practice (Desimone, 2011), and those who argue that effective CPD fits in with 'whatever works well' with that particular individual (Webster-Wright, 2009). In other words, there are no clear links between specific CPD and its impact on pupils learning, although some researchers have attempted to addresses the spectrum of CPD models (see Kennedy 2005; Kennedy, 2014).

The notion of learning being a continuum is interesting, especially given the fact that education in the U.K. has a specific start and end. Furthermore, it could be assumed that because teachers are continuing their career without CPD, that they stop learning new fundamental practitioner skills. Yet, the OECD (2005) argues that lifelong learning is 'a ubiquitous feature of life' rather than 'a special kind of activity that happens from time to time in special places'. Expanding on this perspective, teachers will continue to learn no matter what formal CPD they take part in (Claxton \& Lucas, 2009).

There are a number of different ways CPD can be structured and organized. Despite this, there is little robust evidence to support what constitutes as effective CPD (Hill et al., 2013). Although, recently there has been a shift away from the narrow understandings of 'in service' teacher training. Tannehill et al. (2015) argue that there are a wide range of relevant CPD activities that can be done outside the classroom, such as attending workshops, annual conferences, staff development programs, reading professional journals and books, and pursuing advanced degrees (i.e., Masters in Education).

Much of the research has been conducted across early years, primary, secondary and further education, with a significant portion on the professional development in primary and secondary sectors (Baran and Correia, 2014; Brooks and Gibson, 2012; Kennedy, 2005; Ingleby, 2016). The current body of CPD literature shows support for social constructivists' approaches to teaching and learning (Armour, 2011; Chambers et al., 2012; Williams \& Scott, 2019; Kennedy, 2005; Darling-Hammond et al., 2009; O'Sullivan, 2007). For example, Williams \& Scott (2019) claim that 'professional learning communities' are capable of transforming teaching and learning for both the student and educator. Moreover, Trowler (2008) argues that exploring social interactions with 'tools' supports understanding how effective CPD can facilitate teaching and learning in the $21^{\text {st }}$ century.

In a TEL context, educators report one of the main barriers to effective use is the lack of training in this area (Cheon et al., 2012) Selwyn (2016) amongst others argues that digital training has a tendency to examine the actual technology, rather than how technology can benefit a teacher in the classroom (Mishra \& Koehler, 2006). Thus, it is important that CPD opportunities examine how educators can utilize technology to support technology. 


\section{Aileen Kennedy's (2005) Models Of CPD}

Educators have become pressured to accept new forms of pedagogy (Margolis et al., 2017), alongside making changes to their teaching practice. There is an active debate in the literature around whether it should be the organization (school), or individual (teacher) who takes responsibility of CPD (Weller, 2009). When thought is put into CPD, it can appear complex and this can result in educators not partaking in CPD. Teachers report that CPD can be organized in several different ways, yet, identifying the most appropriate model of CPD is challenging (Stevenson et al., 2016).

While most CPD experiences are considered in the form of enhancing knowledge, some researchers have argued that although knowledge acquisition is important, it is the context in which it is required and subsequently used that actually helps the nature of that knowledge (Eraut, 1994). Eraut (1994, p.20) suggests three contexts in which knowledge is acquired: 1) the academic context, 2) the institutional context, and 3) practice itself. Yet, these contexts do not give consideration to informal discussions and reading, thus, Kennedy (2005) proposes nine categories in which CPD can be grouped. These categories identify the potential sites of knowledge acquisition and considers how they might be adopted and explored (Kennedy, 2005). The nine models of CPD are: training, award-bearing, deficit, cascade, standards-based, coaching/mentoring, community of practice, action research, and transformative; these models enable the author to critique participants' CPD in a TEL context. Kennedy's (2005) spectrum of CPD models and purpose of models are shown below in figure 1.

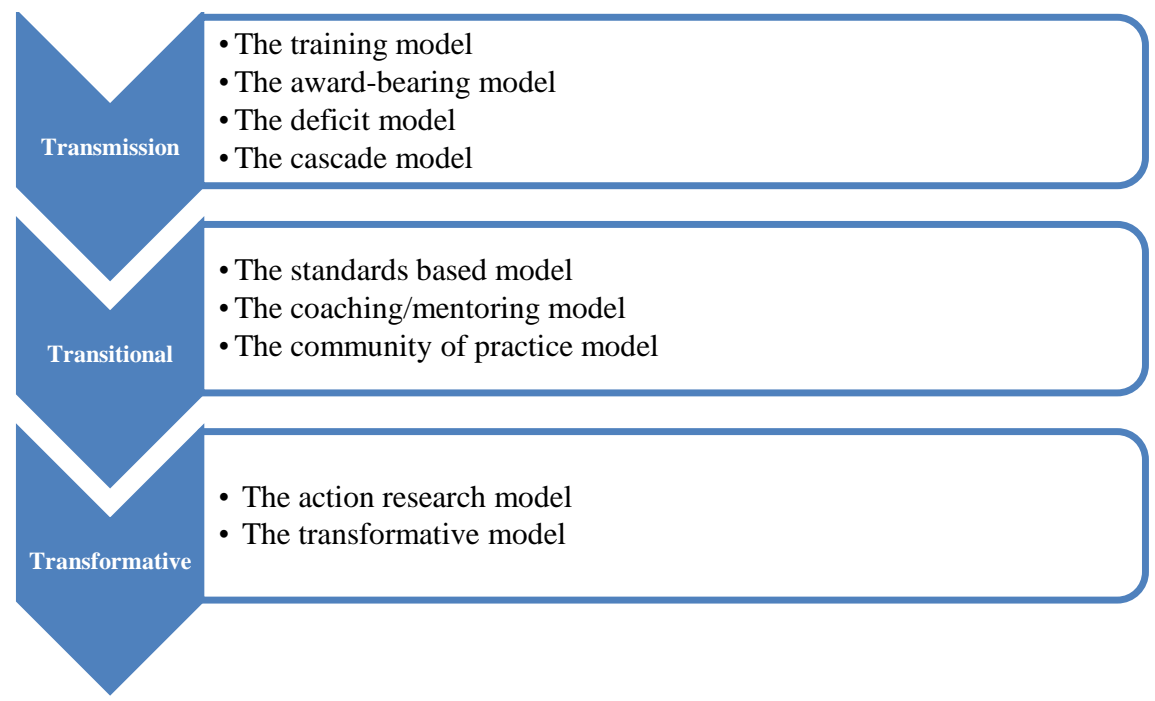

Figure 1: Kennedy's (2005) spectrum of CPD Models.

As teachers move from transmission through to transitional and to transformative CPD, there is increasing capacity for teacher autonomy (Kennedy, 2005).

The training model is a popular model of CPD (Little, 1994) that provides teachers with the opportunity to update their skills with training from an expert. The expert is the individual who delivers the training, whilst the teacher plays a passive role in the session. Most of this training takes place away from a teacher's school, either at another school within a local trust or at an educational conference. For example, teachers across an academy trust would 
come together to take part in basic iPad training by an IT expert. Day (1999) argues that this model of CPD often lacks a connection to the classroom context, thus can be deemed as a failure of these training events. However, this model does support a high degree of quality assurance, where training needs are narrowed and whereby standardization of training is met. At times, agreeing on a particular skill and agreeing a standard to be achieved often overshadows teachers' own development needs. However, in the U.K., there is a notion that standardization of training equates to improvements in teaching and learning (as in Ofsted). In this sense, the training model provides an effective way for stakeholders to control the digital agenda by limiting the teachers to passive roles. Despite these criticisms, the training model is thought of as an effective means of introducing new knowledge (Kennedy, 2014). A good example of this is relates to training for designated safeguarding officers at a school.

The award-bearing model of CPD emphasizes the completion of an award, usually validated by a university. Similarly to the training model, this can be viewed as a mark of quality assurance (Kennedy, 2005). An example of this would be teacher training in the U.K. and attaining Qualified Teacher Status (QTS). While it can be argued that gaining this qualification through the various routes into teaching provides a necessary amount of standardized experiences for those working towards becoming a teacher, researchers have suggested the support on these courses are often perceived as academic, rather than practical (Solomon \& Tresman, 1999). Thus, there is pressure for award-bearing courses to focus on classroom practice. Additionally, there is extensive scrutiny over what the term 'qualified teacher status' actually means (Henderson, 2002; Kennedy, 2005). It is thought that as digital technologies enter the classroom, the term would evolve and that pedagogical uses of these technologies should be integrated into the professional courses. However, generally professional qualifications, such as QTS and a Postgraduate Certificate in Education (PGCE) are perceived as equating to effective teaching and learning practices (Kennedy, 2005).

The deficit model is PD that has been designed specifically to address an aspect of a teacher's performance, such as their ability using technology. In the $21^{\text {st }}$ century, this is a common deficit in practice due to the uncertainty over its purpose in the classroom (Kennedy, 2014). In other words, expectations for competent practice in TEL is not always clear. The deficit model relies on performance management to evaluate an individual's performance and identify their weaknesses. Rhodes \& Beneicke (2002) argue that performance management can raise the standards of teaching to a 'greater efficiency, effectiveness and accountability'. Although, primarily used to address an individual weakness, there are times when poor teaching can be attributed to organizational and management practices. It would be unfair to criticize a teacher's differentiation on iPads when key software/apps have not been purchased/successfully implemented across the school.

The cascade model involves teachers attending training and then disseminating the information to their colleagues (Kennedy, 2005). This is a popular method of training in situations where resources are limited. For example, in a primary setting, the ICT subject specialist would attend a subject specific training day then deliver a presentation on new tablet strategies to other members of staff. Day (1999) argues that this model does not give 'consideration to the principles of participation, collaboration and ownership which had characterized their own learning' (see Trowler, 2008). Other educationalists have discussed the drawbacks to the cascade model, in particular the cascading process which is generally knowledge focused rather than values focused (Solomon \& Tresman, 1999; Day, 1999); this is often referred to as a techniques view of teaching (Eraut, 1994 as cited in Kennedy, 2005). 
Rather than viewing teaching as complex notion, the standards-based model represents a desire to 'create a system of teaching that can validate connections between teacher effectiveness and student learning' (Beyer, 2002, p.243). For example, a teacher must be able to provide evidence that they are capable of planning a lesson and teaching a lesson individually (TS 4). Meeting a 'standard' focuses on the competence of individual teachers at the expense of collaborative learning. In this case, it may be beneficial for departments to plan and share resources together. Smyth (1991) argues that inspection and accountability of such standards indicate a lack of respect for teachers' own capacity to be reflective and critical. Beyer (2002) claims that teacher education must be infused with social purposes, future possibilities, economic realities and moral directions, rather than a standards-based model. Despite the literature often being critical of this model, standards-based CPD does result in participation that allows teachers to engage with it (Kirk et al., 2003). Furthermore, standards-based CPD does provide a common language, making it easier for teachers to engage in professional practice dialogue (Kennedy, 2005).

Coaching and mentoring heavily involves elements of counselling and professional friendship (Rhodes \& Beneicke, 2002), hence the coaching/mentoring model emphasizes the importance of the one to one relationship between two teachers (Kennedy, 2005). This model suggests that coaching and mentoring is where one teacher is a 'novice' in a particular skill area, and the other is an 'expert'. The premise of this model is that CPD can take place in the school context and is enhanced by social dialogue. For example, a trainee teacher would have support from a mentor, who would coach and assess them against the teaching standards. A criticism of this model is that it is hierarchical, and those being mentored may not be able to discuss their beliefs and cultural in relation to teaching. Rogers-Dillon (2005) argues that peer coaching, where colleagues work together to reflect, refine and build new skills is more supportive. Using the previous example, it would be a group of trainee teachers who would reflect together, and coach each other.

However, assessing an individual follows a hierarchical philosophy and this presents problems for Rogers-Dillon (2005) proposal. In other words, for this model to be successful, individuals must be able to communicate well to convey messages about social and cultural norms of teaching.

Although, the coaching/mentoring model and the community of practice model share similarities in the form of being supportive, the main difference is that the latter involves more than two participants (Kennedy, 2005). The other major difference is that it does not follow a hierarchical model. Wenger (1998) argues that all participants are members of one community that includes mutual engagement, developing repertoires, and understanding enterprise. Thus, central to the community of practice model is that learning within a community is a result of interactions within the community and not planned training/courses (Kennedy, 2005). For example, students connect with each other using platforms such as WhatsApp and Facebook groups, and this form of interaction can deliver unplanned provision and consolidate learning. Boreham (2000) suggests learning through communities can be an increasingly powerful site for the creation of new knowledge than existing models.

The action research model is based on participants acting as researchers with a view of improving a situation (Day, 1999). Researchers argue that it has greater impact on practice when the context is relevant (Weiner, 2002; Kennedy, 2005; Williams, 2018). For example, a teacher is able to ask further critical questions of their own practice, in other words, their 
use of TEL in the classroom, if they are involved in collecting the data to propose new iPads for their school. Williams (2018) suggest that the action research model encourages teachers to view research as a process, rather than a product of another researcher. Moreover, this model shifts the balance of power towards teachers by successfully completing research activities. However, Sachs (2003) argues that the extend teachers can effectively critique themselves is determined by the parameters around their practice. Despite this, the action research model has 'significant capacity for professional autonomy' (Kennedy, 2005, p.246).

Finally, the transformative model involves a number of practices and conditions that have already been mentioned, and that support a transformative agenda (Kennedy, 2005; Kennedy, 2014). In other words, this model is not clearly defined by a model like the others, but more of a notion that CPD is a means of supporting educational change (Kennedy, 2005), thus, is effective integration of the previous eight models. Williams (2018) argues that the transformative model provides a sense of awareness of issues of power, more specifically at the agenda being pushed through CPD. However, there are tensions with the realization of conflicting agendas and philosophies.

It can be argued that some of the terminology used in Kennedy (2005) is outdated, for example the communities of practice model is commonly referred to as 'learning communities', and this reflects an emphasis on learning rather than practice. Although, the extent of the categories' purpose is still appropriate (Kennedy, 2014). The models have been designed to help analyze patterns and trends in CPD, rather than a particular model being the sole purpose of CPD (Kennedy, 2014).

\section{CPD IN TEL}

There is a wide consensus that technology can improve the teaching and learning in schools and other educational institutes (Selwyn, 2016; Gao et al., 2017; Fox, 2013; Campbell, 2015; Landson et al., 2015; Junco et al., 2012), and in the U.K., this has led to commitment in supporting technology being used in the classroom (Conservative Party Manifesto, 2017). However, there are questions that challenge if teachers are prepared to effectively use technology in their classroom (Polly \& Brantley-Dias, 2009). Even more so, there is no reference to the word 'technology' in the Teachers' standards.

Prensky's (2001) theory around 'digital natives' has subsequently been developed into discussions around the importance of exposure to technology. However, teachers' technological skills do not always translate into the effective use at a pedagogical level in primary and secondary settings (Wang, 2002). Yet, much of the CPD around technology tends to focus of improving technological skills, thus is disconnected from 'methods courses' and how technology can be effectively implemented into the classroom.

In order for a teacher to successfully implement technology, they must have an understanding of how the technology knowledge (TK) works and is related to technology with content $(\mathrm{CK})$ (in other words, how does this relate to students' learning, and technology with pedagogies (PK) and how can I teach with this?). The difference between TK, CK and PK is discussed in the literature (Williams, 2018; Mishra \& Koehler, 2006). The technological pedagogical and content knowledge framework (TPACK) helps describe the different teachers' knowledge and skills involved for a successful implementation of technology. This is shown below is figure 2 . 


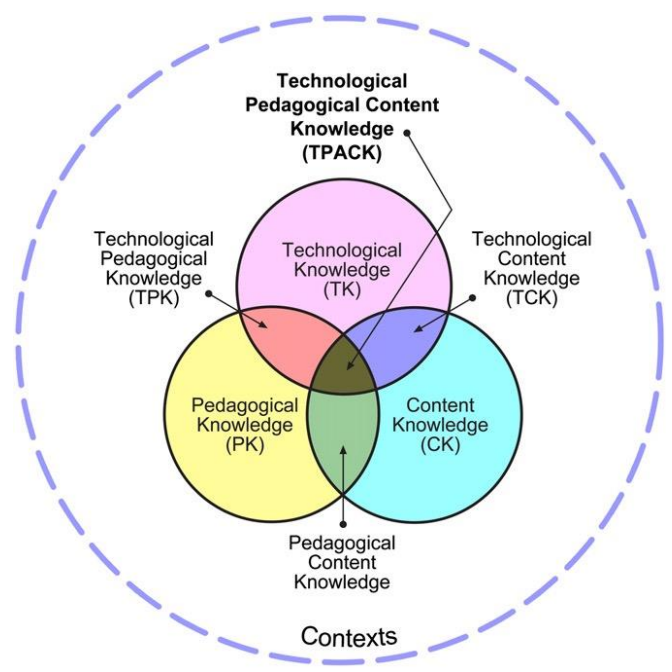

Figure 2: Framework for technological pedagogical and content knowledge (TPACK: Koehler \& Mishra, 2008)

Furthermore, individual distinctions in participants ought to be considered when engaging in CPD, and this reinforces the complexity of TEL associated with PD (McFarlane \& Cartmel, 2012). The complex factors that include personal, social and professional considerations are in direct contrast with policymakers' 'simplistic messages that TEL is representative of pedagogical best practice' (Ingleby et al., 2019). Firstly, considering personal factors addresses the various interpretations of TEL. For example, there are those who have used Blackboard as their new VLE, and those who view it merely as an online filing system. Social factors allow there to be adjustments made for how individuals associate with TEL, and professional factors allow thought for how individuals want students to interact with TEL.

As teachers become more knowledgeable about the benefits of TEL and comfortable with the use of technology in pedagogy, it is predicted that practices with integration of technology will improve (Keengwe et al., 2009). Thus, CPD must attempt to provide opportunities that will impact teachers' beliefs in technology. For example, Ertmer (2005) proposes that teachers must have first-hand experience with technology, where they can observe successful implementation from another teacher or educational professional. This would allow teachers to follow a 'gold standard' of practice which is more productive than admiring the technology out of context (Koehler \& Mishra, 2008). Keengwe et al. (2009) highlights six objectives CPD providers ought to include in their training, as shown below in table 1.

Table 1: CPD in TEL objectives

\section{CPD in TEL objectives}

Learning how to use different technology and tools

Exploring different approaches to managing technology in the classroom

Recognising the critical role of technology in teaching and learning

Understanding how quickly and easily low level assignments can be plagiarised

Recognising relevant laws and guidelines, such as GDPR and COPPA

Identifying specific barriers to technology integration and how to overcome them in the classroom. 
Teachers have reported that time out of lesson attending PD workshops that did not directly benefit their teaching was wasteful, therefore any training in TEL must help them successfully integrate technology into their classroom instruction. Keengwe et al. (2009) argues that there are a range of issues that schools are not addressing to successfully implement TEL, and proposes five strategies educational institutes can make for technology integration, as shown below in table 2 .

Table 2: Strategies for technology integration

\section{Strategies for technology integration}

School leaders must make technology a requirement through grading

Technology professional development activities must align with teachers' time needs

School leaders should install new technology tools that support new educational software

Technology integration specialists / coordinators

Technical personnel to help teachers with their questions

Rodriguez \& Knuth (2000) argue that for effective integration of technology, the following components must be met in CPD: connection to student learning, hands on technology use, variety of experiences, curriculum specific applications, and new role for teachers, collegial learning, active participation, ongoing process, sufficient time, technical support, adequate support, and administrative set up.

In summary, for effective implementation of TEL teachers must have CK, PK and TK (Koehler \& Mishra, 2008), and the training required to develop teachers to this point must take into account their personal, social and professional variables. In particular, the training must consist of ongoing processes, and technical support (Rodriguez \& Knuth, 2000).

\section{Challenges}

A prominent theme across CPD in education is the disconnect between the training that is provided, and how meaningful it is when attempting to improve practice (Drago-Severson 2012). The body of literature that sits around CPD argues that for the most effective outcomes, CPD should provide support over a sustained period. However, due to constraints that include funding, time, structure and policy, this is not often the case (Margolis et al., 2017), and this has fueled a debate around whether it is the school or teacher who should take responsibility of CPD (as in Weller, 2009). Nevertheless, the complexity of CPD can appear

The failure to embrace pedagogical strategies that relate to TEL could be explained by factors such as infrastructure; for a teacher to successfully incorporate TEL (social media, tablets etc.), they would need support from their educational institute. Furthermore, a change in policy, team structure or funding priorities may be required from the school to facilitate the adoption of TEL. Furthermore, CPD training is commonly viewed as a top down process run by school management, and in this way, teachers feel CPD benefits management goals rather than the individuals concerned. However, some teachers are now becoming increasingly aware that CPD can and should be tailored to their professional development needs.

Furthermore, training on digital technologies has a tendency to focus on the actual technology, rather than how the technology can be used in an educational context (Selwyn, 2016; Mishra \& Koehler, 2006). An example of this would be teachers taking part in training 
on the essentials of Twitter, including key functionalities such as: what is a tweet, how to successfully use hashtags, and how to follow an individual. Without being digitally adept, teachers would fail to capitalize on the digital tools at their disposable (Mishra \& Koehler, 2006). Although, this type of training is important for developing an understanding of Twitter, it requires further pedagogical support and guidance to be successfully implemented in the classroom (Selwyn, 2016; Trowler, 2008).

\section{ConCLuding}

In summary, CPD in education has always been complex, nevertheless with the development of technologies it is increasingly important for training and development to have an awareness of what technology can offer teaching and learning. In short, SNS offer educators a platform to collaborate with other professionals and be part of conversations around enhancing their pedagogical practice. Although, this does require teachers to be digitally competent before they can embrace TEL in their CPD. Furthermore, Kennedy's (2005) transformative model of CPD is particularly relevant as part of this thesis when considering processes involved. A key theme that arose from this wider study is that CPD in TEL is underdeveloped. Initial findings report than just under a third of teachers have received training or instruction on social media sites such as YouTube despite $80 \%$ using in their professional practice. It is important to note that, teachers' technological skills do not always translate into the effective use at a pedagogical level in secondary settings. Yet, much of the CPD around technology tends to focus on improving technological skills, thus is disconnected from 'methods courses' and how technology can be effectively implemented into the classroom.

\section{REFERENCES}

Armour, K. M. (Ed.). (2011). Sport pedagogy. London: Pearson.

Atencio, M., Jess, M., \& Dewar, K. (2012). 'It is a case of changing your thought processes, the way you actually teach': Implementing a complex professional learning agenda in Scottish physical education. Physical Education \& Sport Pedagogy, 17(2), 127-144.

Baran, E., \& Correia, A. P. (2014). A professional development framework for online teaching. TechTrends, 58(5), 95-101.

Beyer, L. (2002) The Politics of Standardization: teacher education in the USA, Journal of Education for Teaching, 28, pp. 239-245.

Boreham, N. (2000). Collective Professional Knowledge, Medical Education, 34, pp. 505-506.

Brooks, C., \& Gibson, S. (2012). Professional Learning in a Digital Age. Canadian Journal of Learning and Technology, 38(2), n2.

Campbell, C. (2015). Breaking boundaries In M Henderson and G Romeo (eds), Teaching and Digital Technology: big Issues and Critical Questions. Cambridge, Cambridge Univesity Press pp104-114.

Chambers, F. C., Armour, K. M., \& Makopoulou, K., (2012). Progression in PE teachers' career-long professional learning: Conceptual and practical concerns. European Physical Education Review, $18,62-77$

Cheon, J., Lee, S., Crooks, S.M., and Song, J., (2012). An investigation of mobile learning readiness in higher education based on the theory of planned behaviour. Computers and Education, 59 (2), 1054-1064.

Claxton, G., \& Lucas, B. (2009). School as a foundation for lifelong learning: The implications of a lifelong learning perspective for the re-imagining of school-age education. Leicester: NIACE. 
Conservative Party. (2017). Forward Together: Our Plan for a Stronger Britain and a Prosperous Future: the Conservative and Unionist Party Manifesto 2017. Conservative Party.

Dadds, M. (2014). Continuing professional development: Nurturing the expert within. Professional Development in Education, 40, 9-16.

Darling-Hammond, L. (2006). Powerful teacher education: Lessons from exemplary programs. San

Darling-Hammond, L., Wei, R., Andree, A., Richardson, N., \& Orphanos, S. (2009). Professional learning in the learning profession: Astatus report on teacher development in the United States and Abroad. Dallas, TX: National Staff Development Council.

Day, C. (1999). Developing Teachers: the challenges of lifelong learning. London: Falmer Press.

Department for Education. (2017). Teachers' standards. Gov.uk. https://www.gov.uk/government/publications/teachers-standards

Desimone, L. M. (2011). A primer on effective professional development. Phi Delta Kappan, 92(6), 6871.

Drago-Severson, E., (2012). New opportunities for principal leadership: shaping school climates for enhanced teacher development. Teachers College Record, 114 (3), 1-44.

Eraut, M., (1994). Developing professional knowledge and competence. London, Falmer Press.

Ertmer, P. A. (2005). Teacher pedagogical beliefs: The final frontier in our quest for technology integration?. ETR\&D 53, 25-39

Fox, K. (2013). Twitter in the Classroom. Centre for Learning and Teaching, 13(1) pp.1-3.

Gao, Q., Yan, Z., Wei, C., Liang, Y., \& Lei, M. (2017). Three different roles, five different aspects: Differences and similarities in viewing school mobile phone policies among teachers, parents, and students. Computers and Education, 106(3) pp. 13-25.

Henderson, D. (2002) Rift over Path to Chartered Teacher Status, Times Educational Supplement Scotland, 15 March.

Hill, H. C., Beisiegel, M., \& Jacob, R. (2013). Professional development research consensus, crossroads, and challenges. Educational Researcher, 42(9), 476-487.

Ingleby, E. (2016). We don't just do what we're told to do! Exploring pedagogical technology development needs. International journal of early year's education, 24(1), 36-48.

Ingleby, E., Wilford, B., \& Hedges, C. (2019). Teaching with technology and higher education: A brave new world? Practice: Contemporary Issues in Practitioner Education, 1(1), 1

Junco, R., Elavsky, C. M. \& Heiberger, G. (2012). Putting Twitter to the test: assessing outcomes for student collaboration, engagement and success. British Journal of Educational Technology, 44, 273-287.

Keengwe, J., Onchwari, G., Onchwari, J. (2009). Technology and Student Learning: Toward a LearnerCentered Teaching Model. AACE Journal, 17(1), 11-22.

Kennedy, A. (2005). Models of continuing professional development: A framework for analysis. Journal of in-service education, 31(2), 235-250.

Kennedy, A. (2014). Understanding continuing professional development: the need for theory to impact on policy and practice. Professional development in education, 40(5), 688-697.

Kirk, G., Beveridge, W. \& Smith, I. (2003). Policy and Practice in Education: the chartered teacher. Edinburgh: Dunedin Academic Press.

Koehler, M. J., \& Mishra, P. (2008). Introducing TPCK. Handbook of technological pedagogical content knowledge (TPCK) for educators, 1(1), 3-29.

Landson, M., Straker, K., \& Igbo, I. (2015). Adapting a Social Media Strategy in the Classroom: PEET. The Journal of Nursing Education 54(10), pp. 600. 
Little, J. W. (1994). Teachers' Professional Development in a Climate of Educational Reform, Systemic Reform: perspectives on personalizing education.

Margolis, J., Durbin, R., and During, A., (2017). The missing link in teacher professional development: student presence. Professional Development in Education, 43 (1), 23-35.

McFarlane, K., and Cartmel, J. (2012). "Circles of Change Revisited: Building Leadership, Scholarship and Professional Identity in the Children's Services Sector." Professional Development in Education 38 (5): 845-861.

Mishra, P., and Koehler, M. J., (2006). Technological pedagogical content knowledge: A framework for teacher knowledge. Teachers College Record, 108 (6), 1017-1054.

OECD. (2005). First Results of the Adult Literacy and Life Skills Survey.

OFSTED (2006). The logical chain: Continuing professional development in effective schools. London: Department for Education and Skills, $\mathrm{R}$

O'Sullivan, M. (2007). Creating and sustaining communities of practice among physical education professionals. Journal of Physical Education New Zealand, 40(1), 10-13.

Polly, D., \& Brantley-Dias, L. (2009). TPACK: Where do we go now? Tech Trends, 53 (5) 36-47

Prensky, M. (2001). “Digital Natives. Digital Immigrants Part 1.” On The Horizon 9 (5): 1-6. ISSN: 10748121.

Rhodes, C., and Beneicke, S., (2002). Coaching, mentoring and peer-networking: challenges for management of teachers' professional development in schools. Journal of In-service Education, 28 (2), 297-309.

Rodriguez, G., \& Knuth, R. (2000). Providing Professional Development for Effective Technology Use. North Central Regional Educational Laboratory Critical Issue. Retrieved from http://www.ncrel.org/sdrs/areas/issues/methods/technlgy/te1000.htm

Rogers-Dillon R. H. (2005). Hierarchical qualitative research teams: refining the methodology. Qualitative Research, 5(4), 437-454.

Sachs, J. (2003) The Activist Teaching Profession. Buckingham: Open University Press.

Selwyn, N. (2016). Education and technology: Key issues and debates. Bloomsbury Publishing.

Smyth, J. (1991). Teachers as Collaborative Learners. Buckingham: Open University Press.

Solomon, J. \& Tresman, S. (1999) A Model for Continued Professional Development: knowledge, belief and action, Journal of In-service Education, 25, pp. 307-319.

Stevenson, M., Hedberg, J. G., O'Sullivan, K. A., \& Howe, C. (2016). Leading learning: The role of school leaders in supporting continuous professional development. Professional Development in Education, 42(5), 818-835.

Tannehill, D., van der Mars, H., \& Macphail, A. (2015). Building effective physical education programmes. Burlington, MA: Jones and Bartlett Learning.

Trowler, P., (2008). Cultures and change in Higher Education. Theories and practice. Basingstoke, Palgrave Macmillan.

Wang, Y. (2002). When technology meets beliefs: preservice teachers' perception of the teacher's role in the classroom with computers. Journal of Research on Technology in Teacher Education, 35,150e161.

Webster-Wright, A. (2009). Reframing professional development through understanding authentic professional learning. Review of Educational Research, 79 (2), 702-739.

Weiner, G. (2002). Professional Development, Teacher Education, Action research and Social Justice: a recent initiative in North Sweden, paper presented at the Annual Conference, In-service and Professional Development Association, Birmingham, 1-3 November 2002. 
Weller, S. (2009). What does "peer" mean in teaching observation for the professional development of higher education lecturers? International Journal of Teaching and Learning in Higher education, 21 (1), 25-35.

Wenger, E. (1998). Communities of practice: Learning as a social system. Systems thinker, 9(5), 2-3.

Williams, R. T. (2018). Confidence Interventions: Do They Work?. Asian Journal of Humanity, Art and Literature, 5(2), 123-134. https://doi.org/10.18034/ajhal.v5i2.536

Williams, R. T., \& Scott, C. D. (2019). The Current State of Outdoor Learning in a U.K Secondary Setting: Exploring the Benefits, Drawbacks and Recommendations. ABC Journal of Advanced Research, 8(2), 109-122. https://doi.org/10.18034/abcjar.v8i2.537

\section{How to Cite:}

Williams, R. T. (2020). A Systematic Review of the Continuous Professional Development for Technology Enhanced Learning Literature. Engineering International, 8(2), 61-72. https://doi.org/10.18034/ei.v8i2.506 